\title{
Eye worms, Thelazia gulosa (Railliet and Henry, 1910), In Buffalo, In IRAQ
}

Anisimova E. I.

Scientific and practical center

of the national academy of

sciences of Belarus for

biological resources
M.A.A. Al-Fatlawi

Coll. of Vet Med,/Unive. of

Al-Qadissyia
F.J. Al-Shammary

Coll. of Vet Med,/Unive. of

Al-Qadissyia

\section{Abstract}

We reported 21 infections with Thelazia gulosa, in buffalo, slaughtered at Al-Diwaniya, Najaf and Babyl abattoirs, from john to September 2012.Eyes were examined carefully after uprooted 2 eyes from 328 buffalos for searching about parasite. By gently manipulating, the eyes checking in the conjunctival sacs and corneal surface.6.4\% of examined eyes were have eyeworms.Diwania province showed higher infections rate, than Najaf and Babyl 10.22 \%, $6.42 \%$ and $3 \%$ respectively. The worm burden arranged from 1-3 per eye, with mean number 1.8 parasitel eye.According to months, September showed highly infections rate compared with June, July and August 18\%, 2.38\%, 2.22\% and $0 \%$ respectively.In 12 buffalos we found 1 eye infect with eyeworm, and 9 with 2 eyes.

\section{Introduction}

Thelaziosis is an ocular infestation of several mammals caused by nematodes of the genus Thelazia (Spirurida, Thelaziidae). In the definitive host, adult parasites live in the eyes, Adults of Thelazia spp. can be found under the lids and nictitating membrane, in nasolachrymalducts, conjunctival sacs or in the excretory ducts of lachrymal glands, according to the Thelazia species and associated tissues and are responsible for subclinical to clinical diseases with symptoms such as conjunctivitis, keratitis and ulcers. $(1,2)$.Transmission occurs by means of nonbiting flies, which feed on animal lacrimal secretions and become infected with the 1ststage larvae (L1). These larvae go through further developmental stages while remaining encapsulated in different parts of the vectors' body, as is generally the case for Thelazia species. Infective 3rd-stage larvae (L3) of Thelazia emerge from the labella of infected flies when they feed on the lacrimal secretions of animals, and develop into the adult stage in the ocular cavity. Eyeworms localize under the lids and the third eyelid, in conjunctival sacs, in naso-lacrimal ducts, and in excretory ducts of their glands (depending on the species of Thelazia)
(1).Thelaziosis,in cattle and buffalo, is caused by Thelazia rhodesi Desmarest 1828 , Thelazia gulosa Railliet\& Henry 1910, and Thelazia skrjabini Erschow 1928, which occur in many countries; $\mathrm{T}$. gulosa and $\mathrm{T}$. skrjabini have been reported mainly in the New World $(3,4)$, whereas T. rhodesi is particularly common in the Old World (5). In Italy, $\mathrm{T}$. rhodesi has been reportedseveral times in southern regions; only recently, T. gulosa andT. skrjabini have been identified as the cause of infection in autochthonous cattle from the Apulia region (6).Thirteen species of Musca have been incriminated in the transmission of eyeworms, but only face flies (i.e. Musca autumnalis and Musca larvipara) have been demonstrated, both under experimental and natural conditions, to act as vectors in a few countries (7).Most of the investigations on the Thelazia vectors have been carried out in the USA and Canada by dissecting infected flies. For example, in experimental infection trials, $\mathrm{M}$. autumnalis proved to be the vector of $\mathrm{T}$. gulosa (8), T. skrjabini (2) and T. rhodesi (9), whereas M. larviparawas demonstrated to be the vector of T. rhodesi (10).Over the past few years, the number of surveys on the epidemiology of Thelazia in the intermediate 
hosts havebeen limited by the difficulties in retrieving larvae from vectors because of the low prevalence and mean intensity of infected flies (4). Investigations on the vectors of Thelazia have been carried out on species affecting cows in North America, Slovakia and the ex-USSR by dissecting experimentally and naturally infected flies. Among several species, Musca autumnalis and Musca larvipara(commonly named face flies) have been incriminated in thetransmission of eyeworms $(2,7)$. Munang'andu, et al. (11) reported Thelazia rhodesii in buffalo in Zambia with infection rate $4.3 \%$, with mean parasite number 5.3 parasiteleye. The results of a survey published nearly 30 years ago revealed that the spirurid eyeworms Thelazia gulosa and Thelazia skrjabini were present in 41.9 per cent of 566 bovine heads examined at a Surrey abattoir in southern England during 1976 The prevalence of infection increased during the summer months, Thelazia species recovered from the eyes of cattle throughout the year, the prevalence ranging from 25 per cent in June to 71.9 per cent in

\section{Materials and methods}

During the period from john to September 2012, a double eye was collected from each of 328buffaloslaughtered at a provincial abattoir Diwanyia, Najaf and Babyl. All animals sampled were collected in cooled container to parasitology laboratories in veterinary college, in AlQadissiaya University.The eyeball and tissue surrounding it, containing the lacrimal glands and upper and lower eyelids, were removed with a knife after removal of the head from the carcass, after immobilization, the conjunctival sacs and corneal surfaces of the eyes were gently examined by manipulating the orbital membranes in order to check for the presence of eye-worms. Adult worms were collected using forceps for identification. Not infrequently, the eyelids and some lacrimal glands and their ducts were not collected, but remained on
July(12).Turfrey and Chandler (13) revealed a prevalence of infection of 34 per cent, with the two species,Infected eyesharboured a mean $10.4(3.2)$ worms (range one to 170 worms) and ocular lesions were seen in 4.3 per cent of infected eyes. The longevity of the adult parasite in the final hostmay be up to six months or more (14). Thelazia spp. probably represents one of the most extraordinary taxons among parasitic nematodes because of their relationship with definitive and intermediate hosts. In the definitive host, Thelazia are endoparasitic nematodes living in the anterior eye chamber and thus exposed to the air and the outside environment, just like ectoparasites. Because of the eyeworm's habitat, Thelaziosis is the only nematode infection that can be treated topically, by direct instillation of drugs into the eyes (7).Despite the considerable amount of information on the epidemiology of Thelazia spp. affecting buffalo are not found in IRAQ. So the objective of the present survey was to study the distribution of Thelazia Spp. in the eyes of the buffalo in Diwania, Najaf and Babylon province.

the hide. The eyes were examined in the laboratory (Figure,1 and 2).The lateral canthus was cut and the eye everted. Pressure was applied by the fingers at the base of the lacrimal ducts to expel worms from these sites. The nictitating membrane was reflected and the ducts under it examined by pressure on and incision of the ducts. Worms were fixed and stored in glycerine-alcohol.Excised eyes and surrounding tissues from study buffaloswere flushed with saline, and digital pressure was applied to the Harderian and orbital lachrymal glands to express any parasites present. Parasites recovered were fixed in glycerol alcohol and identified following the descriptions of Skrjabin, et al. (1), Arbuckle and Khalil (12), Soulsby (15) and Urquhar, et al. (16). 
$\begin{array}{llll}\text { AL-Qadisiya Journal of Vet.Med.Sci. } & \text { Vol./12 } & \text { No./1 }\end{array}$

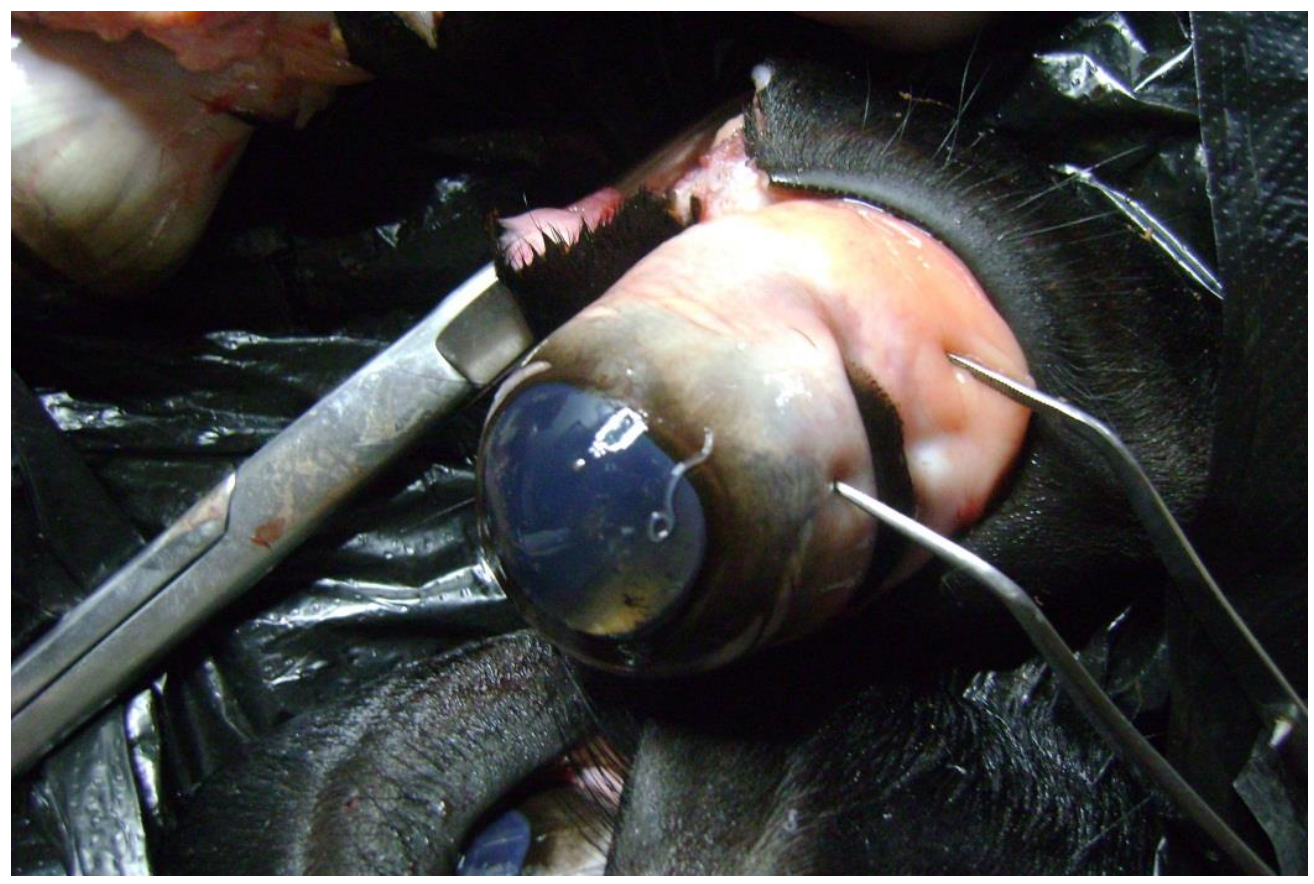

Figure (1) the examination of eyes in parasitology laboratories.

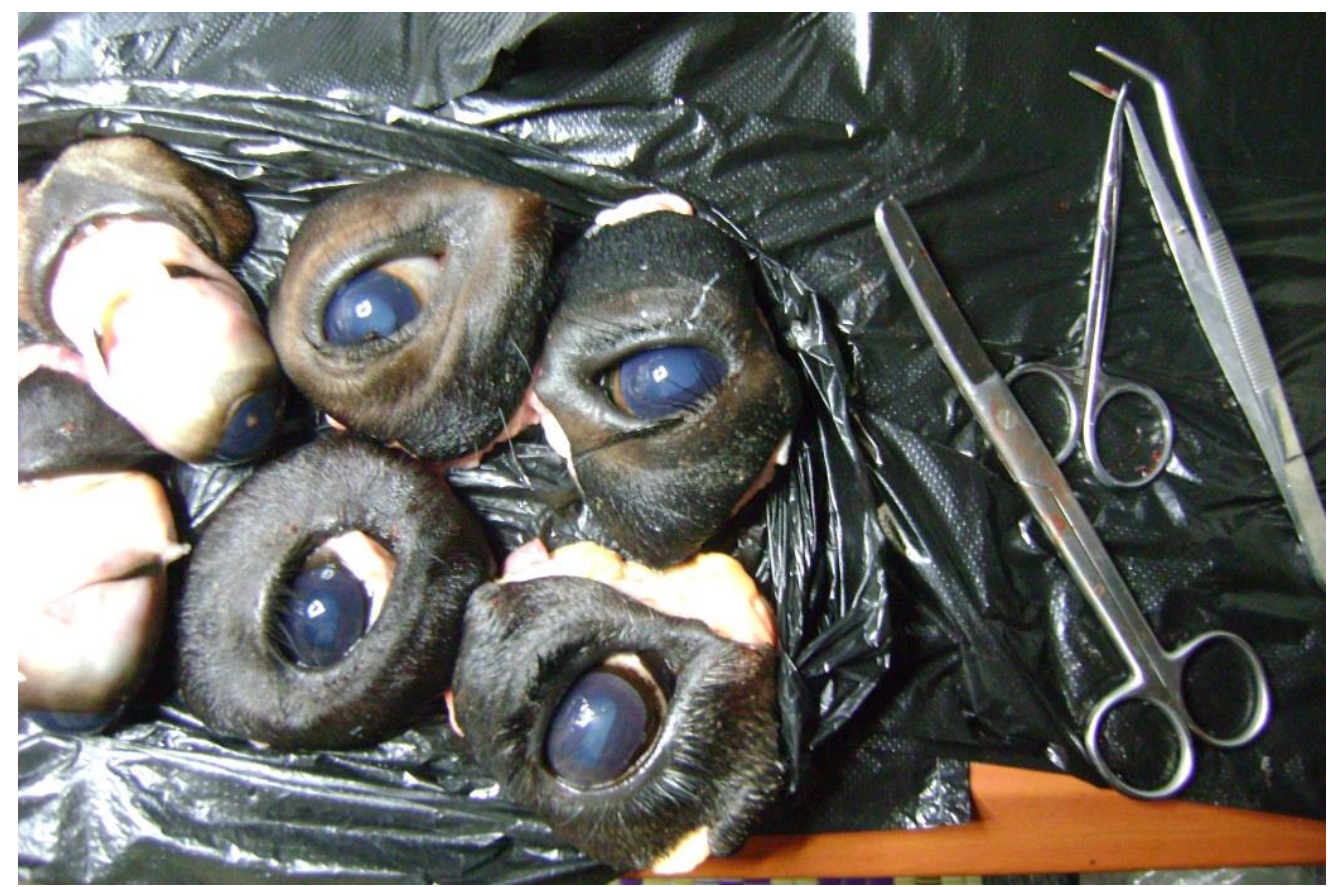

Figure (2) preparing eyes for testing in lab.

\section{Results}

Thelazia gulosa were recovered from the eyes of just $21(6.4 \%)$ of 328 buffalo drawn from 3 province in the central area of
IRAQ, Diwania appear highest infections rate $(10.22 \%)$ (Table,1)(Figure, 3 and 4). 

AL-Qadisiya Journal of Vet.Med.Sci.
Vol./12
No./1

Table (1) showed the rate of infections according to province.

\begin{tabular}{|c|c|c|c|}
\hline \multirow{2}{*}{ Province } & \multicolumn{3}{|c|}{ Buffalo } \\
\cline { 2 - 4 } & Total & infected & $\%$ \\
\hline Diwania & 88 & 9 & 10.22 \\
\hline Najaf & 140 & 9 & 6.42 \\
\hline Babyl & 100 & 3 & 3 \\
\hline Total & 328 & 21 & 6.4 \\
\hline
\end{tabular}

The results of the month survey are summarized in Table 2. Of the 328eyes examined during the period in which two eye per animal were sampled, September showed highest infections rate (18\%).

Table (2) showed the rate of infections according to months.

\begin{tabular}{|c|c|c|c|c|c|c|c|c|c|c|c|c|}
\hline Province & \multicolumn{3}{|c|}{ June } & \multicolumn{3}{|c|}{ July } & \multicolumn{3}{|c|}{ August } & \multicolumn{3}{|c|}{ September } \\
\hline Diwania & Total & infected & $\%$ & Total & infected & $\%$ & Total & infected & $\%$ & Total & infected & $\%$ \\
\hline & 20 & 0 & 0 & 9 & 0 & 0 & 49 & 0 & 0 & 20 & 9 & 45 \\
\hline Najaf & 43 & 0 & 0 & 23 & 1 & 4.3 & 29 & 0 & 0 & 45 & 8 & 17.77 \\
\hline Babyl & 21 & 2 & 9.5 & 13 & 0 & 4.3 & 31 & 0 & 0 & 35 & 1 & 2.85 \\
\hline Total & 84 & 2 & 2.38 & 45 & 1 & 2.22 & 109 & 0 & 0 & 100 & 18 & 18 \\
\hline
\end{tabular}

The mean number of Thelazia gulosa were 1.8 parasiteleye, and mean number was $1-3$ parasite in the infected eyes, 12 buffalo have Thelazia gulosa in one eye, and 9 have parasites in both eyes (Table,3).

Table (3) showed the number of Thelazia gulosa in each eye.

\begin{tabular}{|c|c|c|c|c|}
\hline Province & $\begin{array}{r}\text { Have 1 } \\
\text { eyeworm }\end{array}$ & $\begin{array}{r}\text { Have 2 } \\
\text { eyeworm }\end{array}$ & $\begin{array}{r}\text { Have 3 } \\
\text { eyeworm }\end{array}$ & Total \\
\hline Diwania & 3 & 5 & 1 & 9 \\
\hline Najaf & 2 & 6 & 1 & 9 \\
\hline Babyl & 1 & 2 & 0 & 3 \\
\hline Total & 6 & 13 & 2 & 21 \\
\hline
\end{tabular}



AL-Qadisiya Journal of Vet.Med.Sci.

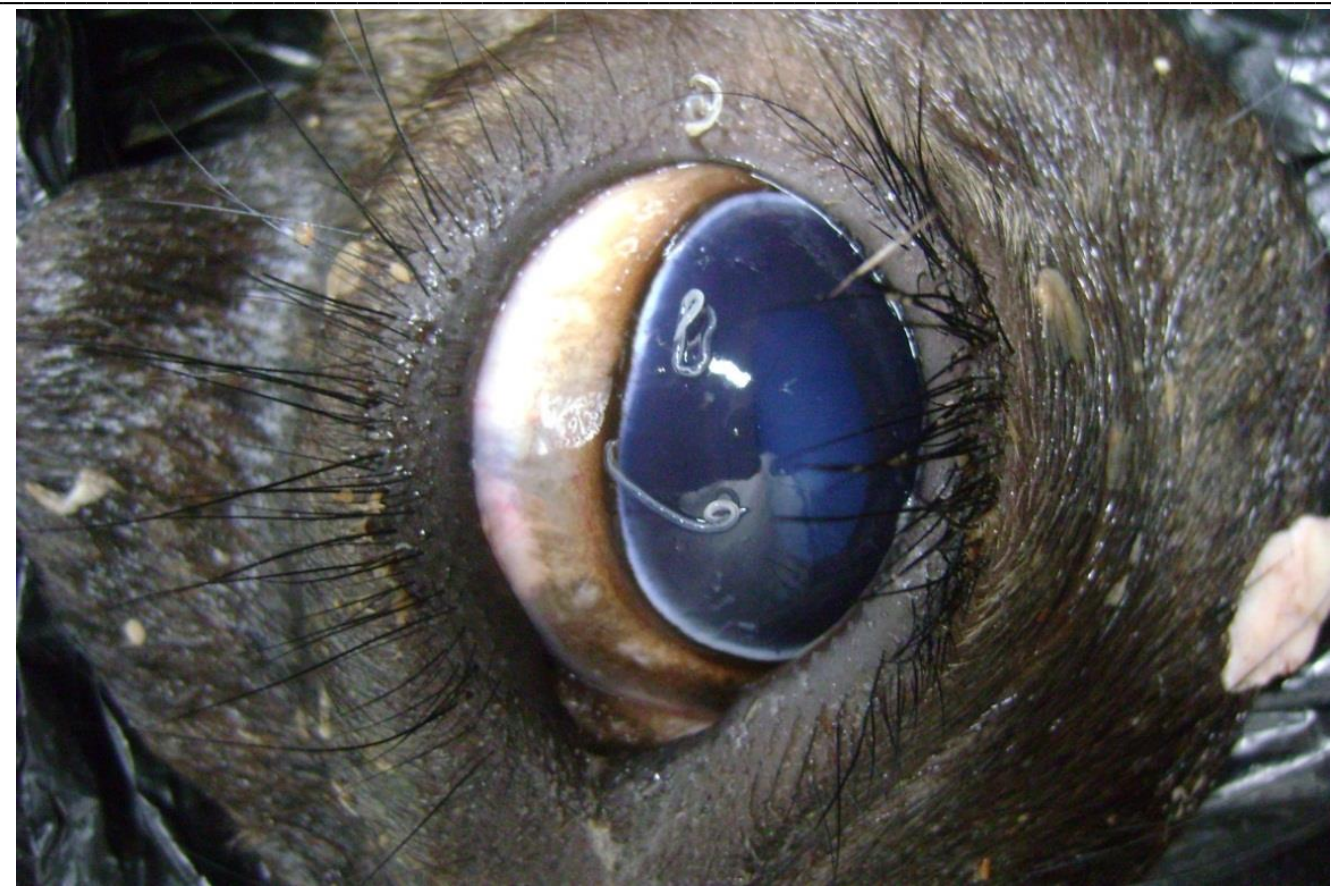

Figure (3) showed buffalo eyes infected with 3 eye worms (Thelazia gulosa)

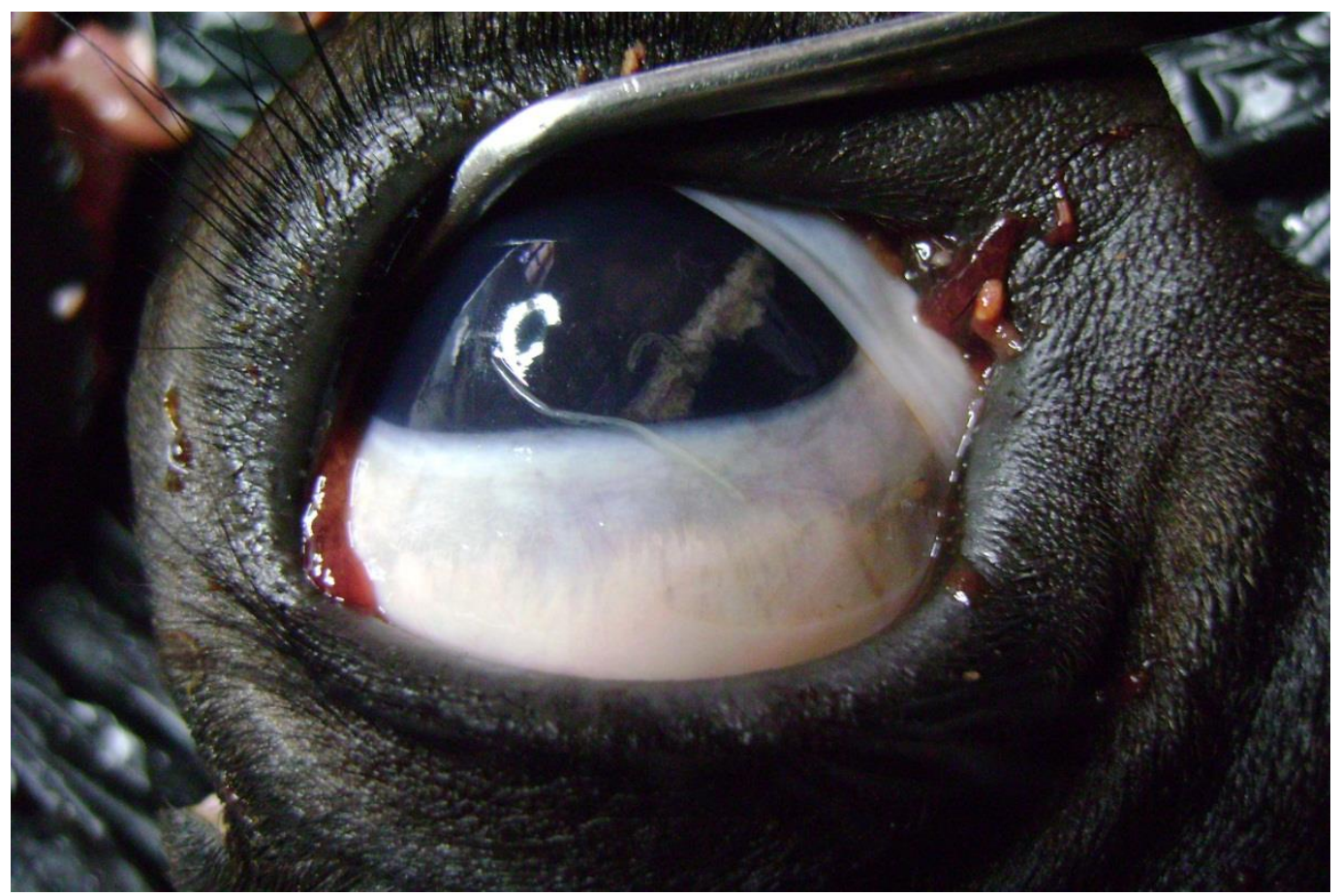

Figure (4) showed buffalo eyes infected with 1 eye worms (Thelazia gulosa)

\section{Discussions}

Despite the fact that very few papers or almost no study ofThelaziosisin buffalo have been reportedfrom IRAQ, this survey suggests that these parasites are extensive. The occurrence of Thelaziosis in an area is influenced by a multifactorial system which comprises hosts, parasite and environmental effects. In the natural foci of Thelaziosis, the Thelazia Spp. and their intermediate and final hosts form an association posing a potential epidemiological threat and it is important 
$\begin{array}{llll}\text { AL-Qadisiya Journal of Vet.Med.Sci. } \quad \text { Vol./12 } & \text { No./1 }\end{array}$

that the existence and localization of such an association should be recognized beforehand so that the situation can be brought under control.In the present study, epidemiological data on Thelaziosis were collected from buffaloes in slaughterhouses in Diwania, Najaf and Babyl. When the data on seasonal prevalence in buffaloes were analyzed it was observed that a higher prevalence of Thelaziosis $(6.4 \%)$. These findings are less than what found in Zambia $(4.3 \%)$ by Munangnandu, et al.(11). That researcher examined just 48 buffalo and that less what we examined in our study328. The high infections rate which found in this study may due to the number of aged buffalo which was high than younger.In fact, we reported that Thelaziosis is definitely most spread in September $(18 \%)$ than June $(9.5 \%)$, July $(2.22 \%)$ and August (0\%). Weather and flies play an important role in that differences, wind in first 3 months was $30-40 \mathrm{Kmlh}$ and was $10-20 \mathrm{Kmlh}$ in September, and that effect in flying vector ( flies).Temperature was higher in in first three months, for they affect the viability of pupa in dump and population of adult flies affected.The worm burden 1-3 in mean 1.8 parasitel eye, and no ocular lesions found in infected eyes. Tweedle, et al, (17) found that the infected eyes harbouredbetween one and four nematodes; no ocular lesions were associated with the presenceof the parasites.

\section{ACKNOWLEDGMENTS}

The authors would like to thank veterinary staff, abattoir of Al-Diwanyia, Najaf and Babyl for helping in collection of samples. Would like to thanks the staff in veterinary clinics in Diwania, Najaf and Babyl for accumulation data.Department of microbiology, college of veterinary medicine, AlQadissyia university, IRAQ. And like to thanks the worker in Scientific and practical center of the national academy of sciences of Belarus for biological resources, Minsk, Belarus for helping in parasite diagnosis and for some comments and suggestions.

\section{References}

1- Skrjabin, K. I., Sobolev, A. A. \&Ivashkin, V.M.Principles of Nematology Vol. IX. Spirurata of Animalsand Man and the Disease Caused by Them. Part. 4:Thelazioidea. (1967), Washington, USA, P 413.

2- O’Hara, J.E., Kennedy, M.J. Development of the nematode Thelazia skrjabini (Nematoda: Thelazioidea) in experimentally infected face flies Musca autumnalis (Diptera: Muscidae). J. Parasitol.(1991), 77 (3), 417- 25.

3- Geden, C. J. \& Stoffolano, J. G. Bovine thelaziasisin Massachussets. Cornell Veterinary. (1980), 70, 344-359.

4- Geden, C. J. \& Stoffolano, J. G. Geographicrange and temporal patterns of parasitization ofMusca autumnalis De Geer by Thelazia spp. inMassachussets with observation on Musca domestica asan unsuitable host. Journal of Medical Entomology. (1981), $18,449-456$.

5- Corba, J. Die geographischeVerbreitung derThelaziose der Rinder in der Welt. Folia Veterinaria. (1985),12: 55.

6- Giangaspero, A., Otranto, D., Vovlas, N. \& Puccini, V. Thelazia gulosa Railliet\& Henry, 1910 andT. skrjabini Erschow, 1928 infection in southern Europe(Italy). Parasite. (2000), 7, 327-329.

7- Stoffolano, J. G. Nematodes associated with thegenus Musca (Diptera: Muscidae). Bulletin of 
$\begin{array}{llll}\text { AL-Qadisiya Journal of Vet.Med.Sci. } & \text { Vol./12 } & \text { No./1 }\end{array}$

theEntomological Society of

America, (1970). 16, 194-203.

8- Geden, C. J. \& Stoffolano, J. G. Development ofthe bovine eyeworm, Thelazia gulosa Railliet and Henry1910 in experimentally infected female Muscaautumnalis De Geer. Journal of Parasitology, (1982). 68, 287-292.

9- Vilagiova, I. Results of experimental studies onthe development of preinvasive stage of worms of thegenus Thelazia Bosc 1819 (Nematoda: Spirurata)parasitic in the eye in the cattle. Folia Parasitologica, (1967). 74,275-280.

10- Keiserovskaya, M. A. The biology of Thelaziarhodesi in Azerbaijzhan. In Issledovaniyapogelmintologiiv Azerbaidzhane (ed. Mikailov, T. K.),(1975). Baku，USSR, pp. 6669.

11- Munangn, H.M.; Chembensofu, M.; Siamudaala,V.M.;Munyeme, M. and Matandiko, W. Thelazia rhodesii in the Africa buffalo, Syncernscaffer, in Zambia/ // Korean J Parasitol., (2011). 49(1):91-94.

12- Arbuckle, J. B. R., Khalil, L. F. A survey of Thelazia worms in theeyelids of British cattle.
Veterinary Record, (1978). 102, 207-210.

13- Turfrey, B. A. \& Chandler, R. L. Incidence of Thelazia nematodesin the eyes of cattle at a research institute in Berkshire.Veterinary Record, (1978). 102:423.

14- Tweedle, $\quad$ M.D.; $\quad$ Fox,M.T.; Gibbons,L.M. and Tennant, K. Change in the prevalence of Thelazia species in bovine eyes in England. Veterinary record, (2005). 157:555-556.

15- Krafsur, E. S. \& Moon, R. D. Bionomics of the face fly, Muscaautumnalis. Annual Review of Entomology, (1997). 42, 503523.

16- Soulsby, E.J.L.Helminth, Arthropods and Protozoa of Domesticated Animals. (1984), 7th ed. London. Balliére: Tindall and Cassell, pp. 289-290.

17- Urquhart, G. M., J. Armour, J. L. Duncan, A. M. Dunn, F. W. Jennings: Veterinary Parasitology. (1988), 2nd Ed. ELBS., Longman, U.K.

18- Tweedle, M.D.; Fox, M.T.; Gibbons, L.M. and Tennant, K. Change in the prevalence of Thelazia species in bovine eyes in England. Veterinary record,(2011). 157: 555-556. 


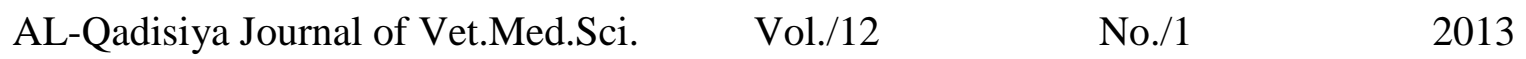

\section{ديدان العين، Thelazia gulosa(Railliet and Henry, 1910)، في في الجمين} الجاموس، في العراق.

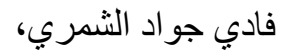 \\ كلية الطُب البيطري/ جادئ اللئرية \\ القادسية
}

$$
\text { كلية الطبر عبد الامير الفتلاوية جامعة }
$$

\author{
أنبسيموفا ألينا أيفانوفنا

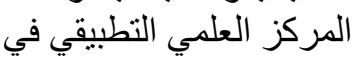 \\ أكاديميه العلوم الوطنيه البيلاروسيه في البيه \\ للابحاث البايولوجيه
}

\section{الخلاصه}

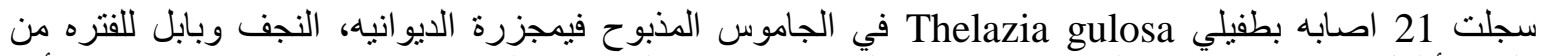

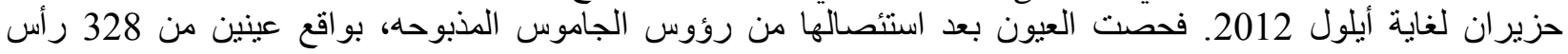

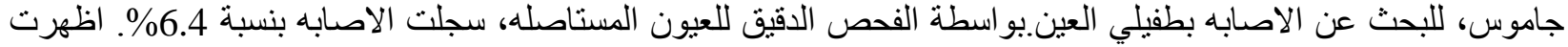

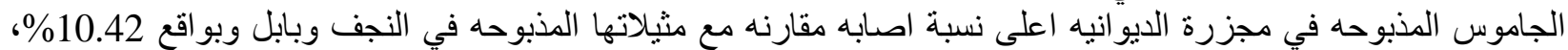

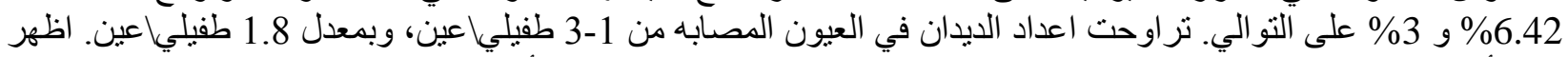

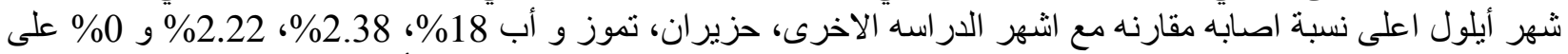

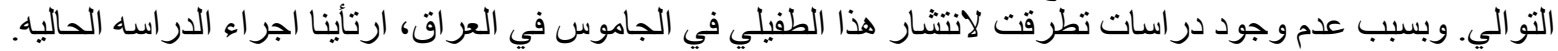
وجدت 12 رأس جاموس يحوي الاصدابه بالطفيلي في عين واحده، بينما حوت 9 حالة في الصابه الطفيلي في كلا العينين. 